\title{
STRESS ULCER PROPHYLAXIS AS A RISK FACTOR FOR TRACHEAL COLONIZATION AND HOSPITAL-ACQUIRED PNEUMONIA IN INTENSIVE CARE PATIENTS: IMPACT ON LATENCY TIME FOR PNEUMONIA
}

\author{
Igor Muzlovič $\check{c}^{1}$ and David Štubljar ${ }^{2}$ \\ ${ }^{1}$ Department of Infectious Diseases, University Medical Centre, Ljubljana, Slovenia; \\ ${ }^{2}$ Department of Research and Development, In-Medico, Metlika, Slovenia
}

SUMMARY - Stress ulcer prophylaxis is associated with bacterial colonization of respiratory tract. The aims of our study were to determine risk factors for trachea colonization (TC), colonization of pharynx (CP) or stomach (CD) and hospital-acquired pneumonia (HAP), and divide the factors into those with high risk and low risk. The study population (ventilated intensive care unit (ICU) patients eligible to receive stress ulcer prophylaxis) was randomized to receive one of three different treatment protocols: ranitidine, sucralfate, and no stress ulcer prophylaxis (control group). Clinical data relative to pre-specified risk factors for TC or HAP were recorded, as follows: APACHE II score (second risk factor), duration of intubation or tracheotomy (third risk factor), duration of mechanical ventilation (fourth risk factor) and duration of hospitalization in the ICU (fifth risk factor). Gastric $\mathrm{pH}$ was recorded and microbiological data regarding stomach, pharynx and trachea were collected on the $1^{\text {st }}, 2^{\text {nd }}, 3^{\text {rd }}$ and $5^{\text {th }}$ day. Fifty-eight out of 81 patients developed HAP (including ventilator-associated pneumonia), which occurred later in patients with gastric content $\mathrm{pH}<4$ or those that were tracheotomized. Stress ulcer prophylaxis was not associated with HAP; however, it was proved as a risk factor for TC. TC was detected in tracheotomized patients and was caused by gram-negative pathogens. $\mathrm{CP}$ was associated with TC, since the majority of patients had CP before TC. A combination of risk factors (APACHE II $>18$, age $>65$, mechanical ventilation and sedation) caused a higher incidence of HAP and lower incidence of TC. HAP was more frequent in patients staying in the ICU for $>10$ days and those with cardiovascular disease as the underlying disorder. Sedation and previous antibiotic therapy correlated with longer latent period (LAT), while higher values of gastric content $\mathrm{pH}$ were related to shorter LAT. The longest LAT was found in patients colonized with Acinetobacter spp. Risk factors that accelerated the occurrence of HAP were found to have caused previous colonization. A combination of risk factors increased the likelihood of TC and HAP, and shortened LAT between TC and HAP.

Key words: Peptic ulcer; Bacteria - growth and development; Healthcare-associated pneumonia; Intensive care units; Risk factors; Tracheostomy

\section{Introduction}

Stress ulcer prophylaxis has traditionally been used as the prevention of upper gastrointestinal bleeding in critically ill patients. A randomized trial comparing patients receiving prophylaxis against stress ulcers and those with no prophylaxis indicated that the use of
Correspondence to: David Štubljar, $M S$, In-Medico, Department of Research \& Development, Mestni trg 11, Metlika, Slovenia E-mail: d.stubljar@gmail.com

Received September 4, 2017, accepted December 5, 2017 
prophylaxis prevented clinically important gastrointestinal bleeding. On the other hand, the study suggested the higher gastric $\mathrm{pH}$ to be associated with bacterial growth in intestinal tract, tracheobronchial colonization, and nosocomial pneumonia ${ }^{1}$. In the past, it was shown that the agents that raise gastric $\mathrm{pH}$ may promote proliferation of bacteria in the stomach, particularly gram-negative bacilli that may originate in the duodenum. Passive esophageal reflux and microaspiration of the gastric content along the endotracheal tube may lead to colonization of the trachea and then to pneumonia ${ }^{2}$.

Nosocomial or hospital-acquired pneumonia (HAP) is defined as an infection of lower respiratory tract, which was not present in the emergency room but emerged 48 hours after hospital admission ${ }^{3}$. HAP is one of the most common nosocomial infections in the intensive care unit (ICU). It occurs in 5 to 10 per 1000 admitted patients, and is up to 20 times more frequent in patients with mechanical ventilation (MV), mainly known as ventilator-associated pneumonia (VAP) ${ }^{4}$. HAP that occurs in patients on MV is divided into early HAP ( 48 hours to 4 days of MV), which is usually primary endogenous, or late HAP occurring after 4 days of MV and is typically secondary endogenous or exogenous ${ }^{4,5}$. HAP prolongs hospital stay by 4-9 days; mortality is $33 \%-50 \%$, and even higher in patients infected with Staphylococcus aureus, Pseudomonas spp., Acinetobacter spp., Klebsiella pneumoniae, and Enterobacter spp. (45\%-71\%) $)^{3,6,7}$. Microorganisms that colonize the pharynx and trachea can come from digestive tract (endogenous route) or outer environment (exogenous route). Previous colonization of upper digestive system is the main cause of $\mathrm{HAP}^{8,9}$. Digestive system colonization may occur due to migration of bacteria from the environment or reproduction of bacteria from intestinal flora ${ }^{10,11}$. Patients that are intubated, tracheotomized or MV have a greater possibility of ascending pharyngeal colonization and subsequent colonization of trachea (TC) is thus easier. $\mathrm{Mi}$ croorganisms that colonize the stomach will gradually colonize the pharynx and frequently come in the respiratory tract with aspirations and cause pneumonia ${ }^{12,13}$.

Thus, TC is the main source of HAP. It is present before the onset of pneumonia in $80 \%$ of patients ${ }^{14-16}$. Literature offers a vast knowledge about risk factors for HAP, but less about TC in ICU patients. The independent risk factors include intubation, tracheotomy,
MV, impaired consciousness, Acute Physiology and Chronic Health Evaluation II (APACHE II) score $>16$, and feeding through nasogastric tube ${ }^{17-20}$. The question is whether these factors and what combination of factors influence the occurrence of TC. There are scarcely any literature data on the relationship of risk factors and temporal occurrence of TC and HAP, and on the impact of risk factors and time between TC and HAP (latency time, LAT). Knowing these facts, we could differentiate patients at a high or low risk of the occurrence of TC and HAP. The data obtained could suggest whether the risk of TC means an equal risk of HAP.

The objectives of this study were to evaluate patients on stress ulcer prophylaxis at the highest risk of both bleeding and pneumonia and to determine which factors influence TC in these ICU patients. We tried to find a causal link between the number of risk factors and the occurrence of colonization and HAP, and to determine LAT between colonization and HAP. Thus, we tried to classify the risk factors into those associated with a high risk and those less likely to cause TC or HAP.

\section{Material and Methods}

\section{Inclusion and exclusion criteria}

The study was designed as a randomized trial and lasted for 10 years, but data were analyzed retrospectively. Ethics Committee of the Republic of Slovenia approved the study design and was run under register $02 / 03 / 98$. The study included ICU patients that were hospitalized, intubated, tracheotomized, or were on $\mathrm{MV}$, and received protection against stress ulcers. The criteria for patient inclusion were expected duration of hospitalization in the ICU for at least 24 hours and age $>15$ years. Only patients with nasogastric tube that were intubated or tracheotomized participated in the study. Exclusion criteria for patients were the presence of HAP at admission to the ICU, immunocompromised patients or leukopenia (less than $2 \times 10^{9} / \mathrm{L}$ ), aspiration at admission, previous intake of antacids, $\mathrm{H}_{2}$ blockers or sucralfate (in the previous 24 hours) and visible bleeding from the stomach or duodenum (Fig. 1). Termination of the experiment was set at the occurrence of HAP, removal of tube or cannula, 72 hours after discharge from the ICU, hospital death, or 21 days of hospitalization. 

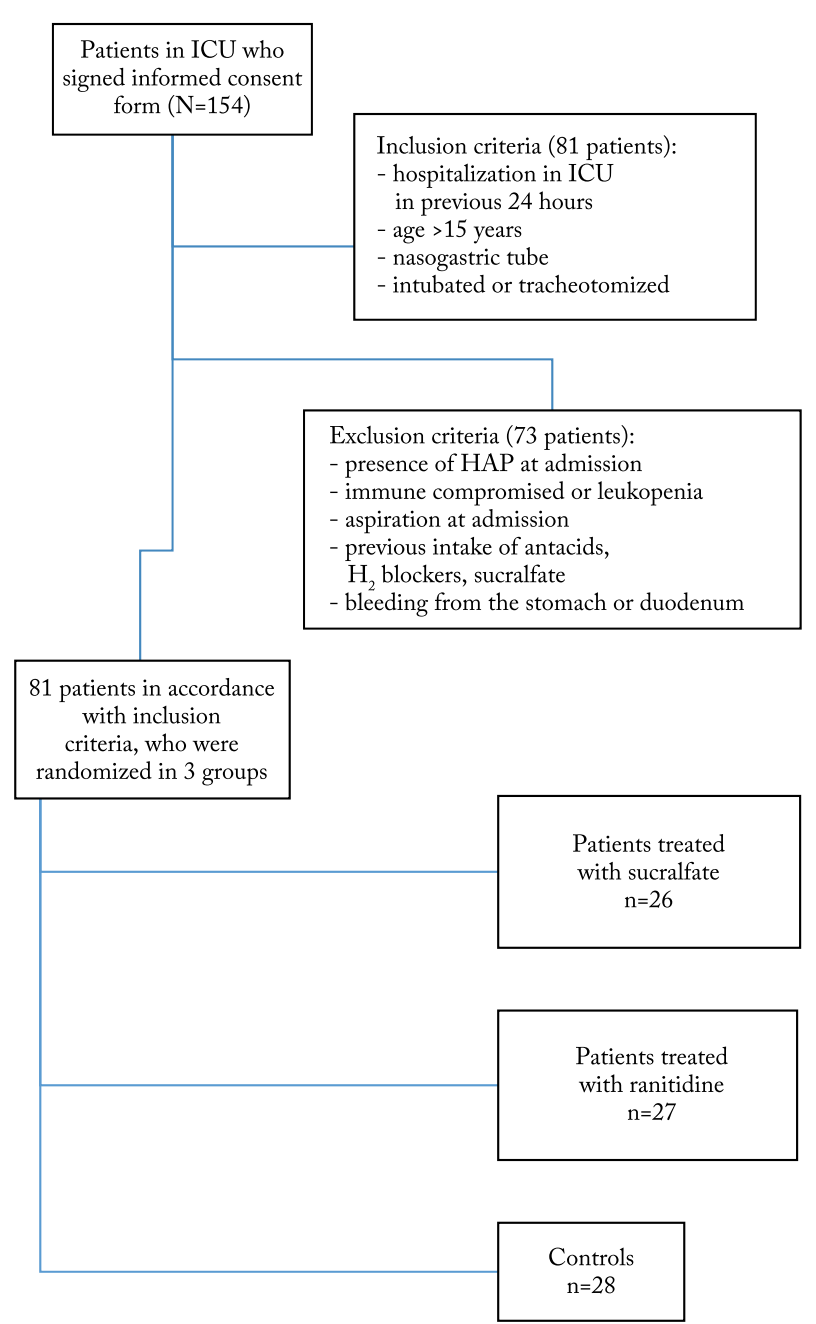

Fig. 1. Work flow of experimental design and group distribution.

\section{Participants and data collection}

A total of 1054 patients were admitted to the medical ICU. Of all eligible patients during the study period, 154 were randomly assigned to a final group and were eventually intubated or tracheotomized for more than 24 hours. In accordance with inclusion criteria, 81 patients could be analyzed. The patients were randomly divided into specified groups using the method of randomized numbers. All patients had equal opportunity to be selected into the control group as the impact of systematic factors on the choice was avoided. Of these patients, group 1 included patients treated with sucralfate (6 $\mathrm{g} / 24 \mathrm{~h} ; 26$ patients) (first risk factor for TC/HAP) and group 2 patients were administered ranitidine, a histamine $\mathrm{H}_{2}$-receptor blocker (300 $\mathrm{mg} / 24 \mathrm{~h} ; 27$ patients). Ranitidine was administered in the form of tablets, $150 \mathrm{mg} / 12 \mathrm{~h}$, which ensured at least $50 \%$ reduction in gastric acid secretion. When macroscopic bleeding was visible, patients received ranitidine parenterally. Sucralfate was prescribed only in the form of granules, 4 to 6 times a day. Meanwhile, 28 patients were selected as controls. The severity of patient condition was evaluated by APACHE II score (second risk factor). We recorded the duration of intubation and tracheotomy (third risk factor), duration of MV (fourth risk factor) and duration of ICU hospitalization (fifth risk factor).

\section{Clinical monitoring of patients}

The patients were fully checked at admission, and if necessary the medical history and clinical picture from the admission department was completed. During testing, we routinely measured vital functions every 3 hours (heart rate, respiration, temperature, blood pressure, intake and excretion of fluids, oxygen saturation) and controlled laboratory values (complete blood count, C-reactive protein, electrolytes, hepatogram, arterial blood gas measurement). The $\mathrm{pH}$ value of stomach content was measured in the morning on an empty stomach, using a Universal Indicator $\mathrm{pH}$-meter (Merck, Germany) with a range of 1 to 10 . The presence of blood in the stomach aspirate was determined each morning using the Hemdetect reagent (DIPRO, Austria). Bleeding was established as the presence of fresh blood or blood mass in the stomach aspirate (or melena), or with positive hematest.

\section{Criteria for diagnosis}

Colonization of trachea and HAP were diagnosed according to the Center for Disease Control (CDC) criteria, as follows: presence of microorganisms in the tracheobronchial aspirates in at least one sample and presence of clinical and laboratory signs for HAP, or presence of the same microorganism in 2 consecutive isolates without clinical signs for HAP ${ }^{21}$. Since pneumonia after mechanical ventilation (ventilator associated pneumonia, VAP) is acquired in hospital units, we defined VAP patients as part of the HAP group.

Criteria for HAP were as follows: criterion I was physical examination for chest percussion or hypophonesis and one of the following: purulent sputum (presence of $>25$ leukocytes and $<10$ epithelial cells in the 
Table 1. Demographic data

\begin{tabular}{|l|l|l|l|l|l|}
\hline & $\begin{array}{l}\text { S group } \\
(\mathrm{n}=26)\end{array}$ & $\begin{array}{l}\text { R group } \\
(\mathrm{n}=27)\end{array}$ & $\begin{array}{l}\text { Control group } \\
(\mathrm{n}=28)\end{array}$ & Total (N=81) & p-value \\
\hline Gender (F/M) & $18 / 8$ & $21 / 6$ & $24 / 4$ & $63 / 18(77.8 \% / 22.2 \%)$ & 0.5 \\
\hline Age (years), median & 67.1 & 68.8 & 74.2 & 70.2 & 0.2 \\
\hline Intubated & 19 & 19 & 22 & $60(74.1 \%)$ & 0.3 \\
\hline Tracheotomized & 7 & 8 & 6 & $21(25.9 \%)$ & 0.3 \\
\hline MV & 15 & 16 & 21 & $52(64.2 \%)$ & 0.4 \\
\hline APACHE II & 19.0 & 19.7 & 19.3 & $19.5(12-24)$ & 0.1 \\
\hline $\begin{array}{l}\text { Underlying disease: } \\
\text { encephalitis } \\
\text { other* }\end{array}$ & 7 & 8 & 2 & $15(18.5 \%)$ & 0.1 \\
\hline $\begin{array}{l}\text { Consciousness: } \\
\text { no disturbance } \\
\text { somnolence } \\
\text { coma }\end{array}$ & 19 & 19 & 26 & $66(81.5 \%)$ & $2(2.5 \%)$ \\
\hline Relaxation & 0 & 2 & 0 & $35(43.2 \%)$ & 0.3 \\
\hline Sedation & 11 & 11 & 13 & $44(54.3 \%)$ & $38(46.9 \%)$ \\
\hline Previous antibiotic treatment & 7 & 16 & 15 & $70(86.4 \%)$ & 0.9 \\
\hline pH value of gastric juice** & $3.8(3-5.2)$ & $4.8(4.2-6.3)$ & $4.2(3-6.5)$ & $4.3(3-6.5)$ & 0.2 \\
\hline
\end{tabular}

$\mathrm{F} / \mathrm{M}=$ female/male; $\mathrm{MV}=$ mechanical ventilation; APACHE = Acute Physiology and Chronic Health Evaluation; *febrile state, polyradiculoneuritis; ** statistically significant difference $(\mathrm{p}=0.002)$ was found between sucralfate $(\mathrm{S})$ and ranitidine $(\mathrm{R})$ groups; comparison of patients who did not receive protection to those receiving $\mathrm{S}$ or $\mathrm{R}$ showed no statistical difference $(\mathrm{p}=0.3)$; comparison of control group and $\mathrm{S}$ group showed a statistically significant difference $(\mathrm{p}=0.03)$ in $\mathrm{pH}$ values.

visual field), positive hemoculture, isolation of microorganisms from aspirate or bronchoalveolar lavage (BAL), biopsy. Criterion II were positive patchy infiltrations on chest $\mathrm{x}$-ray and one of the following: purulent sputum, positive hemoculture, isolation of microorganisms from aspirate or BAL, biopsy and histology. All patients also had to have elevated leukocyte values $\left(>10 \times 10^{9} / \mathrm{L}\right)$ and elevated body temperature $\left(>38^{\circ} \mathrm{C}\right)$ considered as diagnosing criteria.

\section{Bacteriological monitoring to confirm pneumonia}

Samples for microbiological examination were obtained in the morning on days 1, 2, 3 and 5, and then every 48 hours. Gastric juice was collected by nasogastric tube. Blind profound aspiration of trachea and non-bronchoscopic BAL were the basic methods for gathering material for microbiological determination of TC or HAP. When the samples were unrepresentative, we repeated sampling using bronchoscope. Samples were sent for cultivation on blood, chocolate, McConkey agar and thioglycolate broth. Latency time in days between TC and pneumonia was established with confirmation of the same bacterial culture from trachea and lungs. Colonization was determined at three different sites, i.e. stomach, pharynx and trachea. When the same microorganism was isolated from the lung sample and colonizing site, the infectious route was determined.

\section{Statistical analysis}

Statistical analysis was performed by SPSS 21 software (IBM, New York, USA). Univariate analysis compared continuous variables by Student's t-test for data that were normally distributed, or by Wilcoxon rank sum test for abnormal distribution of variables. The $\chi^{2}$-test was used for evaluation of categorical variables. Statistical differences were considered to be significant at $p<0.05$. Logistic regression revealed the impact of a combination of variables (risk factors) on the occurrence of colonization, HAP and LAT. Moreover, Hosmer-Lemeshov test assessed the influence of independent variables (risk factors) on the dependent variable (colonization). The effect of risk factors on latency was shown by the Cox model analysis. 
Table 2. Causative pathogens for colonization of the stomach (CS), pharynx (CP) and trachea (TC)

\begin{tabular}{|l|l|l|l|l|}
\hline Microorganism & CS (\%) & CP (\%) & TC (\%) & Total (\%) \\
\hline Pseudomonas aeruginosa & $4(6.8)$ & $4(0.8)$ & $6(11.3)$ & 14 \\
Acinetobacter calcoaceticus & - & $16(16.2)$ & $7(13.2)$ & 23 \\
Klebsiella pneumoniae & $9(15.3)$ & $3(8.1)$ & $6(11.3)$ & 18 \\
Klebsiella spp. & $9(15.3)$ & $2(5.4)$ & $2(3.8)$ & 13 \\
Escherichia coli & $10(16.9)$ & $7(18.9)$ & $3(5.7)$ & 20 \\
Enterobacter spp. & $9(15.3)$ & $3(8.1)$ & $7(13.2)$ & 19 \\
Citrobacter spp. & $1(1.7)$ & $1(2.7)$ & - & 2 \\
Serratia spp. & - & $1(2.7)$ & - & 1 \\
Haemophilus influenzae & - & - & $1(1.9)$ & 1 \\
Gram-negative & 42 & 37 & 32 & $111(69.8)$ \\
\hline Staphylococcus aureus & $3(5.1)$ & $8(21.6)$ & $11(20.8)$ & 22 \\
MRSA & - & $1(2.7)$ & $1(1.9)$ & 2 \\
Streptococcus faecalis & $5(8.5)$ & - & - & 5 \\
Streptococcus faecium & $1(1.7)$ & - & - & 1 \\
Streptococcus pneumoniae & - & - & $5(9.4)$ & 5 \\
Streptococcus spp. & $2(3.4)$ & - & - & 2 \\
Gram-positive & 11 & 9 & 17 & $37(23.3)$ \\
\hline Candida albicans & $2(3.4)$ & - & $1(1.9)$ & $3(1.9)$ \\
Candida spp. & $4(6.8)$ & $1(2.7)$ & $3(5.7)$ & $8(5.0)$ \\
Total & $59(37.1)$ & $47(29.6)$ & $53(33.3)$ & $159(100)$ \\
\hline
\end{tabular}

\section{Results}

\section{Demographic data}

At randomization, no statistically significant difference was found among the three groups in terms of patient characteristics and other underlying characteristics (Table 1). In addition, no statistically significant difference was found among the three groups in the number of patients at risk with intubation $(\mathrm{p}=0.3)$, tracheostomy $(\mathrm{p}=0.3)$ or mechanical ventilation $(\mathrm{p}=0.4)$ (Table 1). The median stay at ICU for all 81 patients was 38.4 days. APACHE II $<16$ was recorded in five (6.2\%), APACHE II 16-20 in $53(65.4 \%)$ and APACHE II >20 in $23(28.4 \%)$ patients. In total, bleedings were determined in 18 (22.2\%) patients. Most of these were microbleedings, while serious bleeding occurred in one patient from the sucralfate group. More bleedings were noticed in sucralfate group as compared with ranitidine group, but the difference was not statistically significant $(\mathrm{p}=0.4)$. Moreover, in the control group (no prophylaxis against stress ulcer), no bleedings were noticed compared to the other two groups, and a higher gastric juice $\mathrm{pH}$ was recorded compared to ranitidine group (Table 1).

\section{Colonization of stomach, pharynx and trachea}

Colonization of stomach (CS) occurred in 59 (82.8\%) patients, mostly on days 2 and 3 after inclusion in the study (38 patients, $64.3 \%$ ), less on day 4 or 5 (13 patients, 22.1\%). The median time to CS was 3.2 (range 1-9) days. The most common bacteria that colonized digestive system are presented in Table 2. Colonization of pharynx (CP) was recorded in $37(45.7 \%)$ patients and occurred later. On days 2 and 3, colonization was detected in 15 (40.5\%) patients, and on days 4 and 5 in $14(37.8 \%)$ patients. Early colonization (day 1) was observed in two (5.4\%) patients. The median time was 4.2 (range 1-15) days. TC occurred in 53 (65.4\%) patients, mostly on days 2 and 3 , or on days 4 and 5 (18 (34\%) patients both). Between days 6 and 7, colonization occurred in seven (13.2\%) patients, early colonization was found in two (3.8\%) patients and late colonization (after day 7) in eight (14.1\%) patients. The median time was 4.96 (range 1-18) days. Patients 


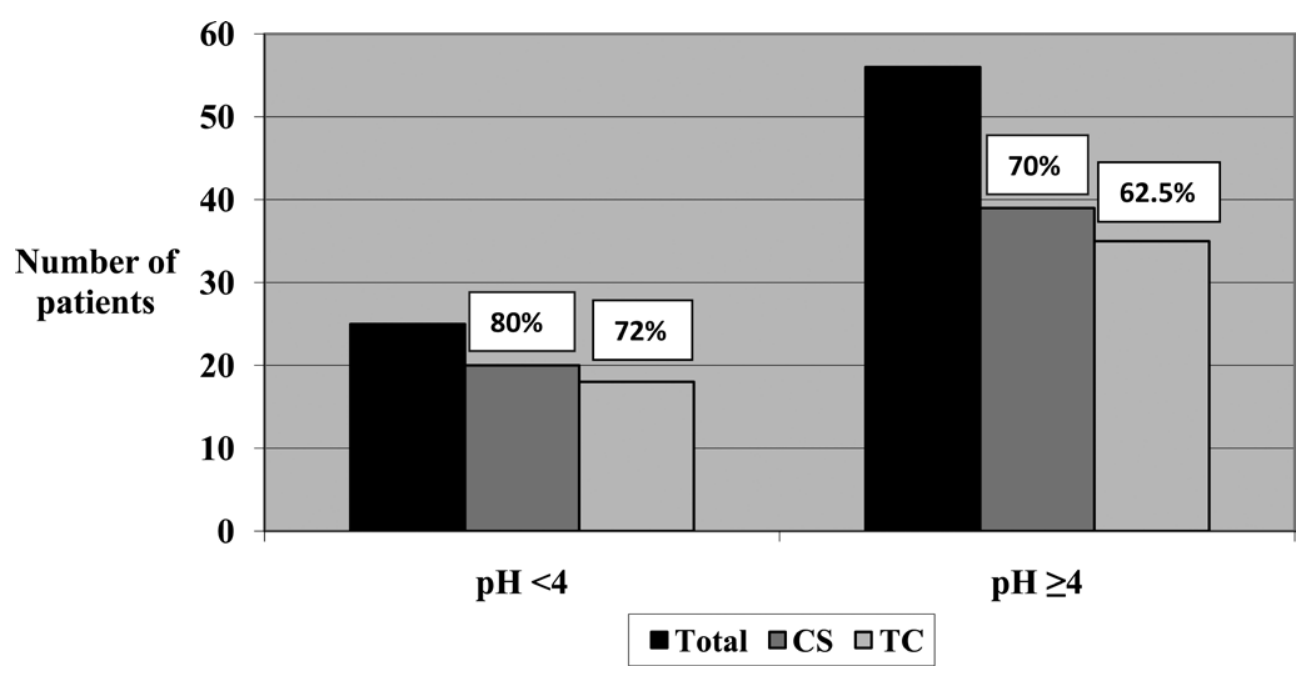

Fig. 2. Colonization of the stomach (CS) and trachea (TC) according to gastric juice pH value.
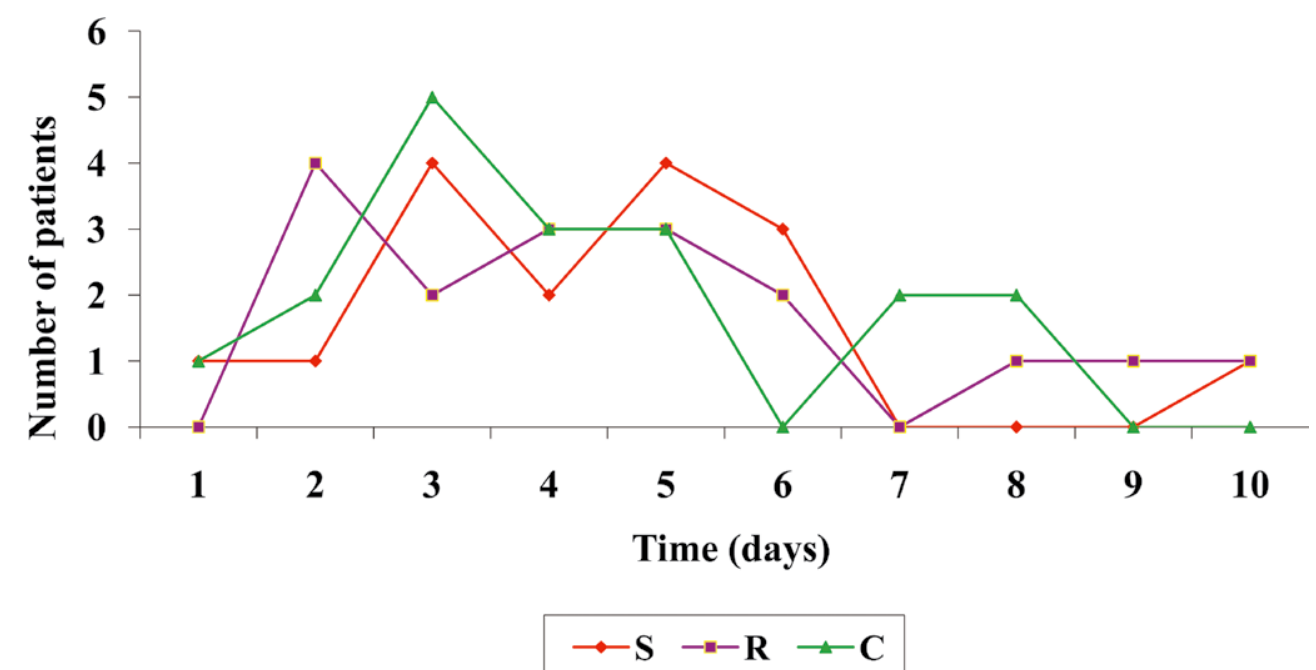

Fig. 3. Pattern of tracheal colonization in patients receiving sucralfate (S), ranitidine $(R)$ and control group $(C)$.

with higher gastric juice $\mathrm{pH}(\mathrm{pH} \geq 4 ; \mathrm{n}=56)$ were more frequently colonized than patients with lower gastric juice $\mathrm{pH}(\mathrm{pH}<4 ; \mathrm{n}=25)$ (Fig. 2), but $\mathrm{CS}$ or TC did not differ between the groups. The colonization and time of colonization onset were not associated with different stress ulcer prophylaxis ( $\mathrm{p}=0.6$ and $\mathrm{p}=0.07$, respectively) (Fig. 3).

\section{Development of hospital-acquired pneumonia}

Fifty-eight (71.6\%) patients developed HAP, which mostly occurred on days 6 and $7(\approx 6.4)$. Seventeen $(29.8 \%)$ patients developed pneumonia on days 4 and 5, slightly less between days 6 and 7 (15 patients, $26.3 \%)$. In ten (17.6\%) patients, HAP emerged on days 8-9. Seven (12.3\%) patients developed HAP between day 10 and day 14. Seventeen (29.3\%) of 58 HAP patients and four (18.2\%) of 22 non-HAP patients died. The occurrence of HAP was not associated with different stress ulcer prophylaxis either $(p=0.8)$ (Fig. 4).

Causative pathogens of HAP are presented in Table 3. Previous association of pneumonia with colonization of digestive system, pharynx or trachea was demonstrated in $36(62.1 \%)$ of 58 patients. Mean- 
Table 3. Isolated pathogens causing hospital-acquired pneumonia and correlation to previous colonization of trachea, pharynx or stomach

\begin{tabular}{|l|l|l|l|}
\hline Microorganism & $\begin{array}{l}\text { HAP } \\
\text { n (mean time in days)/(range) }\end{array}$ & $\begin{array}{l}\text { Previous } \\
\text { colonization (\%) }\end{array}$ & $\begin{array}{l}\text { LAT } \\
\text { mean time in days/(range) }\end{array}$ \\
\hline Pseudomonas aeruginosa & $13(7.0) /(3-12)$ & $6(46)$ & $1.8(1-3)$ \\
Klebsiella pneumoniae & $8(6.4) /(4-10)$ & $6(75)$ & $4.8(4-5)$ \\
Klebsiella spp. & $4(7.3) /(6-9)$ & $4(100)$ & $2.8(1-4)$ \\
Enterobacter spp. & $5(6.8) /(4-12)$ & $5(100)$ & $3.6(2-8)$ \\
Acinetobacter calcoaceticus & $4(10.8) /(8-16)$ & $4(100)$ & $4.8(4-5)$ \\
Haemophilus influenzae & $4(3.8) /(3-5)$ & $1(25)$ & $1.0(1)$ \\
Escherichia coli & $2(8.0) /(8)$ & $1(50)$ & $5.0(5)$ \\
Proteus mirabilis & $1(3) /(3)$ & 0 & 0 \\
Gram-negative & $41(7.5) /(3-16)$ & $27(65.9)$ & $2.9(1-6)$ \\
\hline Staphylococcus aureus & $10(5.5) /(3-11)$ & $7(70)$ & $2.9(1-5)$ \\
MRSA & $2(5.5) /(4-7)$ & $1(50)$ & $2.0(2)$ \\
Streptococcus pneumoniae & $2(3.0) /(3)$ & $1(50)$ & $2.0(2)$ \\
Gram-positive & $14(5.9) /(3-11)$ & $9(64.3)$ & $2.7(1-5)$ \\
\hline Total & $55(7.1) /(3-16)$ & $36(65.5)$ & $2.8(1-6)$ \\
\hline
\end{tabular}

HAP = hospital-acquired pneumonia; LAT = latency time between colonization and development of pneumonia; MRSA = methicillin resistant Staphylococcus aureus

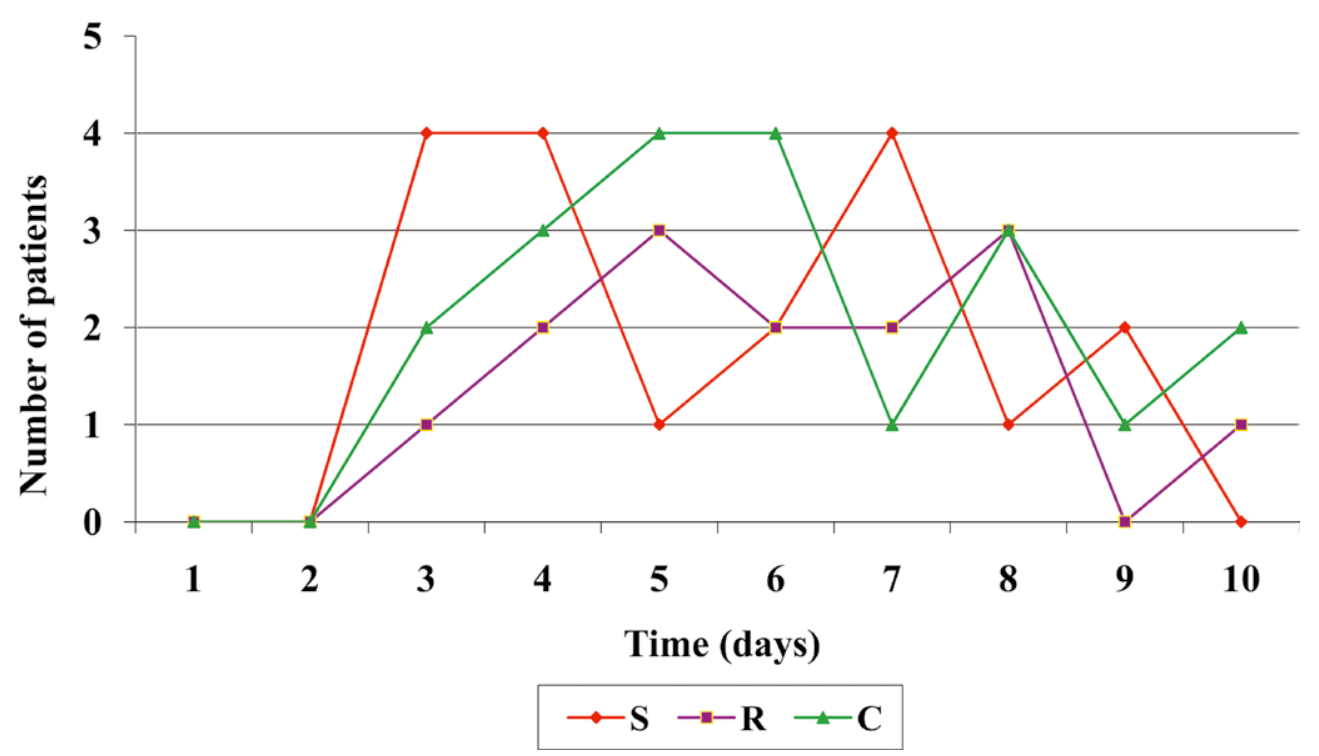

Fig. 4. Pattern of hospital-acquired pneumonia in patients receiving sucralfate $(S)$, ranitidine $(R)$ and control group $(C)$.

while, 22 HAP patients had no connection with previous colonization. Previous TC was recorded in 34 (58.6\%) patients; in 15 (41.7\%) of them, a direct link between previous TC and HAP was established. Furthermore, an infectious route of the same bacteria from $\mathrm{CP}$ to $\mathrm{TC}$ and finally to HAP was found in eight
(22.2\%) patients. Moreover, in six (16.7\%) patients, we proved endogenous route of lower respiratory infection with isolation of bacteria from the stomach first, and then from the pharynx to trachea and to pneumonia. A more accurate route is illustrated in Table 4. The connection between CS and TC was important; 30 out 
Table 4. Route of colonization and occurrence of hospital-acquired pneumonia

\begin{tabular}{|c|c|c|c|c|}
\hline Colonization & HAP & Causative pathogen & Route & LAT (days) \\
\hline Stomach & 6 & $\begin{array}{l}\text { Klebsiella pneumoniae (2) } \\
\text { Klebsiella spp. } \\
\text { Escherichia coli } \\
\text { Enterobacter spp. } \\
\text { Staphylococcus aureus }\end{array}$ & $\mathrm{CS}>\mathrm{CP}>\mathrm{TC}>\mathrm{HAP}$ & $3.0(1-5)$ \\
\hline Stomach & 5 & $\begin{array}{l}\text { Klebsiella pneumoniae (3) } \\
\text { Pseudomonas aeruginosa } \\
\text { Enterobacter spp. }\end{array}$ & $\mathrm{CS}>\mathrm{TC}>\mathrm{HAP}$ & $2.8(1-5)$ \\
\hline Stomach & 2 & Klebsiella spp. (2) & $\mathrm{CS}>\mathrm{HAP}$ & $1.5(1-2)$ \\
\hline Pharynx & 8 & $\begin{array}{l}\text { Acinetobacter calcoaceticus (2) } \\
\text { Staphylococcus aureus (2) } \\
\text { Pseudomonas aeruginosa (2) } \\
\text { Enterobacter } \text { spp. } \\
\text { MRSA }\end{array}$ & $\mathrm{CP}>\mathrm{TC}>\mathrm{HAP}$ & $3.8(2-6)$ \\
\hline Trachea & 15 & $\begin{array}{l}\text { Staphylococcus aureus (4) } \\
\text { Pseudomonas aeruginosa (3) } \\
\text { Acinetobacter calcoaceticus (2) } \\
\text { Enterobacter spp. (2) } \\
\text { Klebsiella pneumoniae } \\
\text { Klebsiella spp. } \\
\text { Haemophilus influenzae } \\
\text { Streptococcus pneumoniae }\end{array}$ & $\mathrm{TC}>\mathrm{HAP}$ & $2.5(1-5)$ \\
\hline No colonization* & 22 & & HAP & \\
\hline
\end{tabular}

HAP = hospital-acquired pneumonia; $\mathrm{CS}=$ colonization of stomach; $\mathrm{CP}=$ colonization of pharynx; $\mathrm{TC}=$ colonization of trachea; $\mathrm{LAT}=$ latency time: *in 22 patients, no colonizing microorganism could be found at any site owing to effective multiple antibiotic therapy administered to patients after symptom onset

of 53 patients with TC had previous CP (95\% CI: $1.27-12.4 ; \mathrm{p}=0.01$ ). The median LAT between the occurrence of colonization and pneumonia was 2.9 (1-6) days.

Acinetobacter and Pseudomonas were associated with TC, compared to other causative pathogens ( $\mathrm{p}=0.003$ ). In contrast to the aforementioned tests, Acinetobacter baumannii had the longest LAT (4.6 days) compared to other pathogens (LAT=2.7 days; $\mathrm{p}=0.010$ ). The longest time for HAP was also observed with that bacterium (10.8 days; $\mathrm{p}=0.010$ ). In our experiment, Acinetobacter baumannii was closely associated with the development of HAP. The duration of LAT between gramnegative and gram-positive pathogens was not statistically different. The cases of pneumonia were mainly caused by Pseudomonas aeruginosa (23.6\%) and Klebsiella pneumoniae (21.8\%).
Besides stress ulcer prophylaxis, other risk factors that could affect TC were analyzed (Table 5). Tested variables showed that tracheotomy compared to intubation represented an independent risk factor that stimulated TC $(\mathrm{HR}=14.9 ; \mathrm{p}=0.017)$. Meanwhile, 34 of $52 \mathrm{MV}$ patients and 19 of 29 patients without MV had confirmed TC ( $p=0.8)$. Statistically significant differences were recorded in the occurrence of HAP between the two groups. HAP developed in 42 of $52 \mathrm{MV}$ patients and 16 of 29 non-MV patients $(80.7 \%$ and $55.2 \%$, respectively; $\mathrm{p}=0.03 ; 95 \% \mathrm{CI}$ : $1.11<\mathrm{HR}<10.69)$. When comparing the two groups according to LAT, there was no significant difference. LAT was 2.9 days in the former group and 2.8 days in the latter group ( $p=0.7)$. Furthermore, the type of prophylaxis against stress ulcer was not found to be an important risk factor $(p=0.07)$ between the patients on 
Table 5. Predictive values of risk factors with calculated hazard ratios (HR) for colonization of trachea (TC)

\begin{tabular}{|l|l|l|l|}
\hline & B & HR to predict TC & p-value \\
\hline Gender (male) & 1.3905 & 4.0170 & 0.1909 \\
Age & 0.0431 & 1.0441 & 0.2013 \\
Comorbidity & -0.5657 & 0.5680 & 0.9416 \\
$\begin{array}{l}\text { Admission } \\
\text { diagnosis: }\end{array}$ & & & 0.4293 \\
$\quad$ encephalitis & 10.7813 & 481110.9820 & 0.9138 \\
$\quad$ tetanus & 13.9228 & 1113293.4000 & 0.8889 \\
$\quad$ other & 18.6115 & 121029757.0000 & 0.8777 \\
Time in ICU & -0.0140 & 0.9861 & 0.4794 \\
APACHE II & 0.1769 & 1.1935 & 0.4491 \\
Intubation & 2.7046 & 14.9483 & $\mathbf{0 . 0 1 7 8}$ \\
/tracheotomy & & & \\
Prophylaxis & & & 0.0717 \\
against stress & & & \\
ulcers & & & 0.7134 \\
S & 0.3512 & 1.428 & $\mathbf{0 . 0 2 6 4}$ \\
R & 2.2426 & 9.4162 & 0.5357 \\
Consciousness & 0.9466 & 2.5770 & 0.5389 \\
Sedation & -1.1374 & 0.3207 & 0.7114 \\
pH value & 0.2336 & 1.2632 & 0.2496 \\
MV (days) & 0.2207 & 1.2469 & 0.3918 \\
Previous & 0.6683 & 1.9510 & \\
antibiotics & & & \\
\hline
\end{tabular}

$\mathrm{B}=$ correlation coefficient ICU = intensive care unit; $\mathrm{MV}=$ mechanical ventilation; $\mathrm{S}=$ sucralfate; $\mathrm{R}=$ ranitidine; $\mathrm{APACHE}=$ Acute Physiology and Chronic Health Evaluation

ranitidine and sucralfate, but prophylaxis with ranitidine significantly contributed to $\mathrm{TC}(\mathrm{HR}=9.42$, $\mathrm{p}=0.026$ ).

Assessing the effect of risk factors on LAT, sedation of patients emerged as a stand-alone independent risk factor for shorter LAT (HR=0.11; $\mathrm{p}=0.053)$. $\mathrm{Pa}-$ tients that were sedated had shorter LAT (Table 6). Moreover, gastric juice $\mathrm{pH}$ was associated with longer LAT $(\mathrm{HR}=2.63 ; \mathrm{p}=0.011)$. Previous antibiotic therapy was associated with shorter LAT. The use of first generation cephalosporins prior to inclusion in the study was associated with sustained LAT $(\mathrm{p}=0.022)$. Other antibiotics did not significantly influence LAT.

\section{Association of risk factors}

All patients with APACHE II $\leq 18$ and no underlying disease survived; on the other hand, 16 of $37 \mathrm{pa}^{-}$
Table 6. Predictive values of risk factors with calculated bazard ratios (HR) for longer latency time (LAT)

\begin{tabular}{|l|l|l|l|}
\hline & B & $\begin{array}{l}\text { HR to } \\
\text { predict } \\
\text { LAT }\end{array}$ & p-value \\
\hline Gender (male) & -0.3774 & 0.6856 & 0.4888 \\
Age & 0.0172 & 1.0173 & 0.4834 \\
Time in ICU & 0.0053 & 1.0053 & 0.7228 \\
APACHE II & -0.2074 & 0.8127 & 0.1884 \\
Intubation/tracheotomy & 0.4217 & 1.5245 & 0.4217 \\
Prophylaxis against & & & 0.8792 \\
stress ulcer & & & \\
S & -0.1108 & 0.8951 & 0.8220 \\
R & -0.3446 & 0.7085 & 0.6123 \\
Consciousness & -0.3890 & 0.6777 & 0.5891 \\
Sedation & $\mathbf{- 2 . 1 7 5 1}$ & $\mathbf{0 . 1 1 3 6}$ & $\mathbf{0 . 0 5 3 3}$ \\
pH value & $\mathbf{0 . 9 6 8 5}$ & $\mathbf{2 . 6 3 4 1}$ & $\mathbf{0 . 0 1 1 1}$ \\
MV (days) & 0.7368 & 2.0893 & 0.3144 \\
Previous antibiotics & $-\mathbf{3 . 2 3 6 9}$ & $\mathbf{0 . 0 3 9 3}$ & $\mathbf{0 . 0 2 2 2}$ \\
\hline
\end{tabular}

$\mathrm{B}=$ correlation coefficient $\mathrm{ICU}=$ intensive care unit; $\mathrm{MV}=\mathrm{me}-$ chanical ventilation; $\mathrm{S}=$ sucralfate; $\mathrm{R}=$ ranitidine; $\mathrm{APACHE}=$ Acute Physiology and Chronic Health Evaluation

tients with APACHE II $>18$ and with underlying diseases died (95\% CI: $1.24<\mathrm{HR}<1.73 ; \mathrm{p}=0.009)$. When combining risk factors, we observed that a combination of APACHE II $>18$, age $>65$ and $\mathrm{MV}$, or APACHE II $>18$, MV and sedation could both statistically significantly predict HAP $(\mathrm{p}=0.010$ and $\mathrm{p}=0.009$, respectively). Death could only be predicted with a combination of APACHE II $>18$ and MV $(\mathrm{p}=0.020)$. APACHE $\mathrm{II}>18$ had no influence on TC, although such patients had longer time to TC (3.25 vs. 4.8 days, $\mathrm{p}=0.5)$. APACHE II showed correlation with HAP development. Five (45.5\%) of 11 patients with lower score and $53(75.7 \%)$ of 70 patients with higher score developed HAP ( $\mathrm{p}=0.040)$. Furthermore, LAT was 1 day in the former group and 3 days in the latter group ( $p=0.009$ ). Combined APACHE II $>18$ and increased number of days on MV caused HAP (25 of 30 patients, $\mathrm{p}=0.011$ ), and more patients died ( 12 out of 30, $\mathrm{p}=0.02$ ) compared to patients with APACHE II $>18$ and without MV. If we add sedation as the third risk factor to our combination, the risk of HAP increased from 25 to 31 of 41 patients ( $\mathrm{p}=0.009$ ) (Fig. 5). Furthermore, gram-negative bacteria caused colonization more often in tracheotomized patients than in 


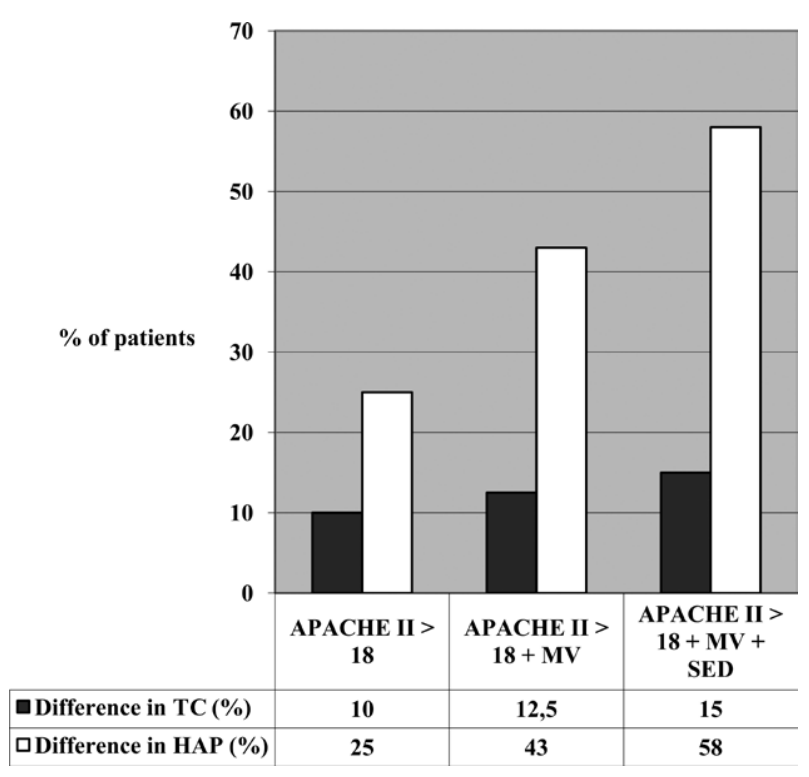

Fig. 5. Effect of combined risk factors on colonization of trachea (TC) and hospitalacquired pneumonia (HAP).

APACHE = Acute Physiology and Chronic Health Evaluation; $\mathrm{MV}=$ mechanical ventilation; $\mathrm{SED}=$ sedation

intubated patients $(95 \% \mathrm{CI}: 0.02<\mathrm{HR}<0.85 ; \mathrm{p}=0.029)$, and in vulnerable and elderly patients (95\% CI: $0.00<\mathrm{HR}<0.36 ; \mathrm{p}=0.001$ ).

\section{Discussion}

No relevant difference was recorded among the three randomization groups. Prophylaxis of stress ulcers did not influence the occurrence of CS or TC, but it was shown that higher gastric juice $\mathrm{pH}$ could lead to bacterial spread. However, Prod'hom et al. ${ }^{2}$ and Eddleston et al..$^{22}$ found that retrograde bacterial colonization from the stomach to the pharynx and trachea occurred more frequently in patients treated with ranitidine than in those treated with sucralfate. The second result section in our study presents results relative to the route of infection leading to HAP in the entire study population. The stomach, pharynx and tracheal colonization are relevant because it can lead to pneumonia. A relationship between TC and HAP was found, which is clinically useful. Secondly, the CS and $\mathrm{CP}$ support the hypothesis that these two anatomical regions act as bacterial reservoirs associated with the occurrence of TC or HAP. We assumed that the risk factors for colonization were similar to the risk factors that influence the occurrence of HAP, but they were not. Chevret et al. ${ }^{23}$ in their multicentre study found that significant risk factors for HAP were trauma, value of Simplified Acute Physiology Score (SAPS) >9, APACHE II $>16$, oxygen therapy with $>50 \%$ oxygen, impaired respiratory reflexes, supported breathing and coma. In our study, we found factors such as APACHE II $>18$ and presence of MV. There was no difference in HAP between intubated and tracheotomized patients, but an important risk factor was tracheotomy that lasted for $>3$ days. Meanwhile, intubation time was not a risk factor for TC. This ratio indicated that tracheotomized patients suffered from HAP later than intubated patients. Similar was shown for MV that lasted for $>3$ days. In the past, MV was also confirmed as an independent risk factor for $\mathrm{HAP}^{24}$. Turković et al. ${ }^{25}$ evaluated the impact of tracheotomy on VAP. Tracheotomy was associated with a reduced duration of MV after VAP onset, but only if patients were tracheotomized at the moment of VAP onset. According to some authors ${ }^{26,27}$, the risk may be higher in the first 5 days of ventilation, when the incidence of HAP is usually higher. In our study, HAP was more common in the first 7 days after admission to the ICU, which coincided with the results of our previous trial ${ }^{28}$.

Hospital-acquired pneumonia affected $50 \%$ of patients that were tracheotomized for $>3$ days. With the addition of APACHE II $>18$ as a risk factor (two risk factors), there were no significant changes in the number of HAP patients. However, when we took into account the third risk factor (MV), the number of patients increased from $50 \%$ to $66.7 \%$. Combined with the fourth risk factor (sedation), the percentage of patients that developed HAP increased to $79.6 \%$. Thus, the risk of HAP increased with the increasing number of risk factors, similar to the results published by Chevret et al..$^{23}$.

A similar study was conducted by Garrouste $e t$ al..$^{29}$; they followed risk factors for the development of pneumonia in $86 \mathrm{MV}$ patients. Statistically significant risk factors were parenteral nutrition and progressive underlying disease. Age, duration of hospitalization in the ICU, severity of any disease, immunosuppression or enteral nutrition, previous antibiotic therapy, or drugs against stress ulcer (ranitidine or sucralfate) did not have any effect on the occurrence of HAP. Comparable results were obtained in our study; HAP was not connected with age, time in the ICU, protection 
against stress ulcers, disturbance of consciousness, because it was present in most patients. Some authors ${ }^{30}$ cite an underlying disease as an independent risk factor. We observed a similar pattern (but without statistical significance), i.e. patients that developed HAP frequently had an underlying cardiovascular disease, whereas sex, age, admission diagnosis and relaxation did not affect the incidence of HAP.

Nevertheless, our results differ slightly from the data published by Beck-Sague et al. ${ }^{31}$ who found a statistically significant difference in the occurrence of HAP in MV patients receiving H2-receptor antagonists, oral intubated patients and those having previously received cefazolin. In our previous study ${ }^{28}$, the use of sucralfate or ranitidine had no significant impact on the occurrence of HAP, as we similarly noted in the current research. Considering the fact that elevation of gastric acid $\mathrm{pH}$ enables growth of gram-negative bacteria in the stomach, which then can reach the pharynx and lungs by aspiration, the risk of HAP would be greater if we apply a drug against stress ulcers, which raises gastric acid $\mathrm{pH}^{8,32,33}$. However, in our study, despite the difference in the gastric juice $\mathrm{pH}$ between sucralfate and ranitidine, the prophylaxis against stress ulcers did not play an important role in the occurrence of HAP. Otherwise the use of drugs against stress ulcers was previously proven as a factor for the occurrence of HAP in patients on $\mathrm{MV}^{34,35}$. Torres et $a .^{36}$ and Bonten et al. ${ }^{37}$ included altered $\mathrm{pH}$ of gastric contents and the presence of nasogastric tube as accelerating risk factors for CS. However, these factors did not influence TC. They concluded that gastric juice $\mathrm{pH}$ was not significantly different with the administration of sucralfate or ranitidine, and CS was more common at higher $\mathrm{pH}$ values. Moreover, our research showed that the use of drugs was an independent risk factor for TC when applying sucralfate or ranitidine $(p=0.03)$. The administration of sucralfate or absence of drugs did not affect the occurrence of TC, but taking ranitidine could predict $\mathrm{TC}$, as confirmed by the fact that elevated gastric juice $\mathrm{pH}$ shortened LAT between TC and HAP. Although CS was slightly more common in patients with elevated $\mathrm{pH}$ (with the administration of ranitidine), the levels of $\mathrm{pH}$ in our study did not affect the occurrence of TC.

Furthermore, Bonten et al. ${ }^{38}$ report that long-term MV was an independent risk factor for TC. A correlation was also found with previous $\mathrm{CP}$ with the same microorganism. Microaspiration from colonized pharynx can be the cause of 'early pneumonia' in patients on MV. In our study, no significant difference in the occurrence of TC was determined when intubation or tracheotomy was present. MV was not associated with the occurrence of TC. However, we found a connection with previous use of first-generation cephalosporins. In these patients, the incidence of colonization was lower than in those without having previously taken cephalosporins. In patients with MV, CP represented a risk factor for 'early pneumonia', while previous use of broad-spectrum antibiotics a risk factor for "late pneumonia" 5,39 . Previous use of antibiotics in some trials increased the likelihood of $\mathrm{HAP}^{40-43}$. We found that patients having taken first-generation cephalosporins prior to inclusion in the study developed HAP significantly later than those having used no antibiotics.

Feldman et $a l .{ }^{43}$ investigated colonization of upper and lower respiratory tract and concluded that colonization occurred very fast with microorganisms that later caused pneumonia. In our study, we recorded similar results. CS occurred between days 2 and 3 (mean 3.2 days), $\mathrm{CP}$ between days 2 and 3 (mean 4.2 days), and TC between days 2 and 5 (mean 4.95 days). Regarding LAT, we could conclude that stomach or pharynx were an important source of TC. The CP by Acinetobacter and Pseudomonas was often associated with TC ( $=0.05)$. We also found that TC with $A c i-$ netobacter and Pseudomonas occurred later $(\mathrm{p}=0.003)$. TC was significantly more common in patients that had oropharyngeal colonization for more than 2 days, meaning that $\mathrm{CP}$ was an independent risk factor for late TC ( $\mathrm{p}=0.04)$. The same was confirmed by Ewig et $a l .^{44}$ and Safdar et $a l . .^{45}$, who concluded that colonization of the upper respiratory system was an independent risk factor for TC, and had greater probability for the occurrence of early HAP.

Oropharyngeal colonization by the gram-negative bacteria Pseudomonas and Acinetobacter has been proven to be an independent risk factor for $\mathrm{TC}^{28,46,47}$. When comparing correlation of $\mathrm{CP}$ with microorganisms, the incidence of TC was significantly higher when the pharynx was colonized by Enterobacteriaceae, Pseudomonas and Acinetobacter $(\mathrm{p}=0.022)$. Chastre and Fagon ${ }^{47}$ emphasized the great importance of microorganisms that colonized the upper respiratory tract for the emergence of HAP in patients on MV. In the 
early period (the first week), the microorganisms involved were Staphylococcus aureus, Streptococcus pneumoniae and Haemophilus influenzae. Later, these microorganisms were replaced by resistant microorganisms such as Pseudomonas aeruginosa, MRSA and Acinetobacter baumannii. These microorganisms are probably the main cause of higher mortality. Similar findings were observed by Brusich et al. ${ }^{48}$, who found that gram-negative bacteria were the leading causative agents (82.03\%) of VAP and were even multidrug-resistant. Thus, we must also consider fungi, especially in immunocompromised patients ${ }^{49}$. Bonten et al. ${ }^{38}$ found shorter LAT in patients that had previous TC than in those that previously had only CP. Accordingly, pneumonia occurred later in infections by Pseudomonas aeruginosa than by other gram-negative bacteria. In the present study, we found a significantly longer LAT for Acinetobacter infections $(\mathrm{p}=0.01)$ and slightly longer LAT for Pseudomonas aeruginosa $(\mathrm{p}=0.08)$ compared to other pathogens. The difference could be clinically relevant. However, LAT was shorter when the same bacteria had previously colonized the trachea compared to previous CP. Although the results showed significantly longer LAT in patients with APACHE II $>18$, clinically significantly longer LAT in tracheotomized versus intubated patients $(\mathrm{p}=0.09)$, and clinically shorter LAT in patients with higher $\mathrm{pH}$ of the stomach contents $(p=0.07)$, logistic regression analysis showed that the independent risk factors affecting LAT were only $\mathrm{pH}$ of gastric contents $(\mathrm{p}=0.01)$ and previous antibiotic treatment $(\mathrm{p}=0.020)$. Higher $\mathrm{pH}$ of gastric contents was associated with shorter LAT, and secondly taking first-generation cephalosporins extended LAT. The use of broad-spectrum antibiotics affected the initial CP and thus prevented the development of pneumonia in the first 4 days, thus enabling late (generally after 4 days) colonization and infection by gram-negative pathogens. This could be in line with the fact that these patients usually acquired HAP caused by microorganisms that extend LAT. Moreover, our study found the rate of TC to be statistically lower in patients with gastric $\mathrm{pH}<4.0$, suggesting that the beneficial effect of sucralfate is essentially obtained in the group of patients able to maintain low gastric $\mathrm{pH}$. Our results also agree with the results of a study ${ }^{2}$ that showed correlation between the microorganisms recovered from the lower respiratory tract and those from the stomach, but not with those found in the pharynx.
In our study, several limitations were observed. Our sample size was too small to make definite conclusions on the predictive values of specific risk factors for TC or HAP. Moreover, the selection of patients included in the study could be more representative, but it is difficult to gather a larger sample of appropriate and comparable patients for three test groups. Patients that are on MV, intubated or tracheotomized have already been staying at the ICU for quite a long time. However, our analysis of LAT between TC and HAP is a valuable add to the existing literature. To our knowledge, this is one of the rare studies to assess correlation between different steps of infection in respiratory system, especially in recent literature. Therefore, our study represents an important update on this subject. We observed several steps of colonization which could be evaluated further in future studies in a larger sample size.

\section{Conclusions}

The problem of correlation between TC and HAP in this manner was processed for the first time and presented in this study. Risk factors that influenced HAP did not always influence TC. Risk factors that significantly worsened disease outcome (increased mortality) were identified as APACHE II $>18$, presence of heart and circulatory system disease as primary disease, previous use of antibiotics, and presence of MV. In most cases, HAP was preceded by TC. Higher gastric content $\mathrm{pH}$ was related to shorter LAT, and antibiotic therapy was an independent risk factor for longer LAT. The results of this trial deepen the knowledge about HAP pathogenesis and suggest some possibilities for early prevention of hospital infections and rational use of antibiotics.

\section{References}

1. Cook D, Guyatt G, Marshall J, Leasa D, Fuller H, Hall R, et al. A comparison of sucralfate and ranitidine for the prevention of upper gastrointestinal bleeding in patients requiring mechanical ventilation. Canadian Critical Care Trials Group. N Engl J Med. 1998;338(12):791-7.

DOI: 10.1056/NEJM199803193381203

2. Prod'hom G, Leuenberger P, Koerfer J, Blum A, Chiolero R, Schaller MD, et al. Nosocomial pneumonia in mechanically ventilated patients receiving antacid, ranitidine, or sucralfate as prophylaxis for stress ulcer. A randomized controlled trial. Ann 
Intern Med. 1994;120(8):653-62. DOI: 10.7326/0003-4819120-8-199404150-00005

3. American Thoracic Society, Infectious Diseases Society of America. Guidelines for the management of adults with hospital-acquired, ventilator-associated, and healthcare-associated pneumonia. Am J Respir Crit Care Med. 2005;171(4):388416. https://doi.org/10.1164/rccm.200405-644ST

4. Peleg AY, Hooper DC. Hospital-acquired infections due to gram-negative bacteria. N Engl J Med. 2010;362(19):1804-13. DOI: 10.1056/NEJMra0904124.

5. Rotstein C, Evans G, Born A, Grossman R, Light RB, Magder $\mathrm{S}$, et al. Clinical practice guidelines for hospital-acquired pneumonia and ventilator-associated pneumonia in adults. Can J Infect Dis Med Microbiol. 2008;19(1):19-53.

6. Kollef MH, Shorr A, Tabak YP, Gupta V, Liu LZ, Johannes RS. Epidemiology and outcomes of health-care-associated pneumonia: results from a large US database of culture-positive pneumonia. Chest. 2005;128(6):3854-62. https://doi.org/10.1378/chest.128.6.3854

7. Kollef MH, Morrow LE, Baughman RP, Craven DE, McGowan JE Jr, Micek ST, et al. Health care-associated pneumonia (HCAP): a critical appraisal to improve identification, management, and outcomes - Proceedings of the HCAP Summit. Clin Infect Dis. 2008;46(Suppl 4):S296-334. https://doi. org/10.1086/526355

8. Kusahara DM, da Silva Canezin CC, Angélica M, Peterlini S, da Luz Gonçalves Pedreira M. Oropharyngeal colonization, and gastric and tracheal bacterial translocation, in children experiencing mechanical ventilation. Acta Paul Enferm. 2012;25 (3):393-400.

9. Kieninger AN, Lipsett PA. Hospital-acquired pneumonia: pathophysiology, diagnosis, and treatment. Surg Clin North Am. 2009;89(2):439-61. https://doi.org/10.1016/j.suc.2008.11.001

10. Gritz EC, Bhandari V. The human neonatal gut microbiome: a brief review. Front Pediatr. 2015;3:17.

DOI: $10.3389 /$ fped.2015.00017

11. Putignani L, Del Chierico F, Petrucca A, Vernocchi P, Dallapiccola $\mathrm{B}$. The human gut microbiota: a dynamic interplay with the host from birth to senescence settled during childhood. Pediatr Res. 2014;76(1):2-10. DOI:10.1038/pr.2014.49

12. Esperatti M, Ferrer M, Theessen A, Liapikou A, Valencia M, Saucedo LM, et al. Nosocomial pneumonia in the intensive care unit acquired by mechanically ventilated versus nonventilated patients. Am J Respir Crit Care Med. 2010;182(12): 1533-9. DOI: 10.1164/rccm.201001-0094OC

13. Guggenbichler JP, Assadian O, Boeswald M, Kramer A. Incidence and clinical implication of nosocomial infections associated with implantable biomaterials - catheters, ventilator-associated pneumonia, urinary tract infections. GMS Krankenhhyg Interdiszip. 2011;6(1):Doc18. DOI: 10.3205/dgkh000175

14. Waters B, Muscedere J. A 2015 Update on Ventilator-Associated Pneumonia: New Insights on Its Prevention, Diagnosis, and Treatment. Curr Infect Dis Rep 2015;17(8):496. DOI: 10.1007/s11908-015-0496-3

15. Alp E, Voss A. Ventilator associated pneumonia and infection control. Ann Clin Microbiol Antimicrob. 2006;5:7. https://doi. org/10.1186/1476-0711-5-7

16. Drakulovic MB, Bauer TT, Torres A, Gonzalez J, Rodríguez MJ, Angrill J. Initial bacterial colonization in patients admitted to a respiratory intensive care unit: bacteriological pattern and risk factors. Respiration. 2001;68(1):58-66. https://doi.org/10.1159/000050464

17. Ewan VC, Sails AD, Walls AW, Rushton S, Newton JL. Dental and microbiological risk factors for hospital-acquired pneumonia in non-ventilated older patients. PLoS One. 2015;10 (4):e0123622. https://doi.org/10.1371/journal.pone.0123622

18. Alp E, Güven M, Yildiz O, Aygen B, Voss A, Doganay M. Incidence, risk factors and mortality of nosocomial pneumonia in intensive care units: a prospective study. Ann Clin Microbiol Antimicrob. 2004;3:17. DOI: 10.1186/1476-0711-3-17

19. Wałaszek M, Kosiarska A, Gniadek A, Kołpa M, Wolak Z, Dobroś W, et al. The risk factors for hospital-acquired pneumonia in the intensive care unit. Przegl Epidemiol. 2016;70(1): 15-20.

20. Kalil AC, Metersky ML, Klompas M, Muscedere J, Sweeney DA, Palmer LB, et al. Management of adults with hospital-acquired and ventilator-associated pneumonia: 2016 Clinical Practice Guidelines by the Infectious Diseases Society of America and the American Thoracic Society. Clin Infect Dis. 2016;63(5):e61-e111. DOI: 10.1093/cid/ciw353

21. Horan TC, Andrus M, Dudeck MA. CDC/NHSN surveillance definition of health care-associated infection and criteria for specific types of infections in the acute care setting. Am J Infect Control. 2008;36(5):309-32.

DOI: $10.1016 /$ j.ajic.2008.03.002

22. Eddleston JM, Vohra A, Scott P, Tooth JA, Pearson RC, McCloy RF, et al. A comparison of the frequency of stress ulceration and secondary pneumonia in sucralfate- or ranitidinetreated intensive care unit patients. Crit Care Med. 1991;19 (12):1491-6.

23. Chevret S, Hemmer M, Carlet J, Langer M. Incidence of risk factors of pneumonia acquired in intensive care units. Results from a multicenter prospective study on 996 patients. Intensive Care Med. 1993;19:256-64.

24. Kalanuria AA, Ziai W, Mirski M. Ventilator-associated pneumonia in the ICU. Crit Care. 2014;18(2):208. DOI: 10.1186/ cc13775

25. Turković TM, Lukić A, Pažur I, Ožegić O, Obraz M. The impact of tracheotomy on the clinical course of ventilator-associated pneumonia. Acta Clin Croat. 2016;55:100-9.

26. Gadani H, Vyas A, Kar AK. A study of ventilator-associated pneumonia: incidence, outcome, risk factors and measures to be taken for prevention. Indian J Anaesth. 2010;54(6):535-40. DOI: $10.4103 / 0019-5049.72643$.

27. Lin WC, Chen CW, Wang JD, Tsai LM. Is tracheostomy a better choice than translaryngeal intubation for critically ill pa- 
tients requiring mechanical ventilation for more than 14 days? A comparison of short-term outcomes. BMC Anesthesiol. 2015;15:181. DOI: 10.1186/s12871-015-0159-9

28. Muzlovič I, Trampuž A. Hospital infection prevalence study in the intensive care units in Slovenia. In: Grosek Š, Dragaš AZ, eds. Hospital Hygiene and Infection Control in Intensive Care Units. The IFIC Workshop. Ljubljana: University Medical Centre Ljubljana, 1998; p. 100-4.

29. Garrouste-Orgeas M, Chevret S, Arlet G, Marie O, Rouveau M, Popoff N, et al. Oropharyngeal or gastric colonization and nosocomial pneumonia in adult intensive care unit patients. A prospective study based on genomic DNA analysis. Am J Respir Crit Care Med. 1997;156:1647-55. https://doi.org/10.1164/ajrccm.156.5.96-04076

30. Zhu J, Zhang X, Shi G, Yi K, Tan X. Atrial fibrillation is an independent risk factor for hospital-acquired pneumonia. PLoS One. 2015;10(7):e0131782.

DOI: $10.1371 /$ journal.pone.0131782

31. Beck-Sague CM, Sinkowitz RL, Chinn RY, Vargo J, Kaler W, Jarvis WR. Risk factors for ventilator-associated pneumonia in surgical intensive-care-unit patients. Infect Control Hosp Epidemiol. 1996;17:374-6.

32. Bowton DL. Nosocomial pneumonia in the ICU-year 2000 and beyond. Chest. 1999;115(3 Suppl):28S-33S. https://doi. org/10.1378/chest.115.suppl_1.28S

33. Niederman MS, Craven DE. Editorial response: devising strategies for preventing nosocomial pneumonia - should we ignore the stomach. Clin Infect Dis. 1997;24:320-3.

34. Bonten MJM, Gaillard CA, Ramsay G. The pathogenesis of nosocomial pneumonia in mechanically ventilated patients. In: Vincent JL, ed. Yearbook of Intensive Care and Emergency Medicine. Heidelberg: Springer-Verlag, 1995; p. 711-27.

35. Dey A, Bairy I. Incidence of multidrug-resistant organisms causing ventilator-associated pneumonia in a tertiary care hospital: a nine months' prospective study. Ann Thorac Med. 2007;2(2):52-7. DOI: 10.4103/1817-1737.32230

36. Torres A, E1-Ebiary M, Soler N, Monton C, Fabregas N, Hernandes C. Stomach as a source of colonization of respiratory tract during mechanical ventilation: association with ventilator-associated pneumonia. Eur Respir J. 1996;9:1729-35. DOI: 10.1183/09031936.96.09081729

37. Bonten MJ, Gaillard CA, van der Gees S, van Tiel FH, Beysens AJ, Smeets HG, et al. The role of intragastric acidity and stress ulcus prophylaxis on colonization and infection in mechanically ventilated ICU patients. A stratified, randomized doubleblind study of sucralfate versus antacids. Am J Respir Crit Care Med. 1995;152:1825-34.

https://doi.org/10.1164/ajrccm.152.6.8520743
38. Bonten MJ, Bergmans DC, Ambergen AW, de Leeuw PW, van der Geest S, Stobberingh EE, et al. Risk factors for pneumonia, and colonization of respiratory tract and stomach in mechanically ventilated ICU patients. Am J Respir Crit Care Med. 1996;154(5):1339-46. https://doi.org/10.1164/ajrccm.154.5.8912745

39. Hanson LC, Weber DJ, Rutala WA. Risk factors for nosocomial pneumonia in the elderly. Am J Med. 1992;92:161-6. DOI: https://doi.org/10.1016/0002-9343(92)90107-M

40. Mehta RM, Niederman MS. Nosocomial pneumonia in the intensive care unit: controversies and dilemmas. J Intensive Care Med. 2003;18:175-88. https://doi.org/10.1177/0885066603254249

41. El-Solh AA, Pietrantoni C, Bhat A, Okada M, Zambon J, Aquilina $\mathrm{A}$, et al. Colonization of dental plaques: a reservoir of respiratory pathogens for hospital-acquired pneumonia in institutionalized elders. Chest. 2004;126:1575-82. https://doi. org/10.1016/S0012-3692(15)31374-X

42. Pesola GR. Ventilator-associated pneumonia in institutionalized elders: are teeth a reservoir for respiratory pathogens? Chest. 2004;126:1401-3. https://doi.org/10.1016/S0012-3692(15)31345-3

43. Feldman C, Kassel M, Cantrell J, Kaka S, Morar R, Goolam $\mathrm{MA}$, et al. The presence of sequence of endotracheal colonization in patients undergoing mechanical ventilation. Eur Respir J. 1999;13:546-51.

44. Ewig S, Torres A, El-Ebiary M, Fabregas N, Hernandez C, Gonzales J, et al. Bacterial colonization patterns in mechanically ventilated patients with traumatic and medical head injury. Incidence, risk factors and association with ventilator-associated pneumonia. Am J Resp Crit Care Med. 1999;159: 188-98. https://doi.org/10.1164/ajrccm.159.1.9803097

45. Safdar N, Crnich CJ, Maki DG. The pathogenesis of ventilator-associated pneumonia: its relevance to developing effective strategies for prevention. Respir Care. 2005;50(6):725-39.

46. George DL, Falk PS, Wunderink RG, Leeper KV Jr, Meduri GU, Steere EL, et al. Epidemiology of ventilator-acquired pneumonia based on protected bronchoscopic sampling. Am J Resp Crit Care Med. 1998;158:1839-47. https://doi.org/10.1164/ajrccm.158.6.9610069

47. Chastre J, Fagon JY. Ventilator-associated pneumonia. Am J Respir Crit Care Med. 2002;165:867-903. https://doi.org/10.1164/ajrccm.165.7.2105078

48. Brusich KT, Acan I, Filipčić NV. Ventilator-associated pneumonia: comparing cadaveric liver transplant and non-transplant surgical patients. Acta Clin Croat. 2016;55:360-9.

49. Park DR. The microbiology of ventilator-associated pneumonia. Respir Care. 2005;50(6):742-63. 


\section{Sažetak \\ PROFILAKSA STRESNOG ULKUSA KAO ČIMBENIK RIZIKA \\ ZA KOLONIZACIJU TRAHEJE I BOLNIČKI STEČENU PNEUMONIJU KOD BOLESNIKA U JEDINICI INTENZIVNOG LIJEČENJA: UTJECAJ NA VRIJEME LATENCIJE ZA PNEUMONIJU}

\section{Muzlovič i D. Štubljar}

Profilaksa stresnog ulkusa povezana je s bakterijskom kolonizacijom respiratornog trakta. Cilj našega istraživanja bio je utvrditi čimbenike rizika za kolonizaciju traheje (KT), ždrijela (KŽd) ili želuca (KŽe) i bolnički stečenu pneumoniju (BSP) te podijeliti čimbenike na one $s$ visokim rizikom i niskim rizikom. Ispitivana populacija (bolesnici u jedinici intenzivnog liječenja (JIL) s ventilacijom koji imaju pravo na profilaksu stresnog ulkusa) randomizirani su za primjenu jedne od tri različite vrste liječenja: ranitidin, sukralfat i kontrolnu skupinu. Zabilježeni su klinički podaci u odnosu na unaprijed određene čimbenike rizika za kolonizaciju traheje ili BSP te APACHE II (drugi čimbenik rizika), trajanje intubacije ili traheotomija (treći čimbenik rizika), trajanje mehaničke ventilacije (četvrti čimbenik rizika) i trajanje hospitalizacije u JIL-u (peti čimbenik rizika). Zabilježeni su želučani $\mathrm{pH}$ i prikupljeni su mikrobiološki podaci o želucu, ždrijelu i dušniku 1., 2., 3. i 5. dana. Od 81 bolesnika BSP se razvila u njih 58 (uključujući upalu pluća povezanu s ventilatorom), i to kasnije u bolesnika s $\mathrm{pH}$ želučanog sadržaja <4 ili onih koji su traheotomizirani. Profilaksa stresnog ulkusa nije bila povezana s BSP-om, no dokazana je kao čimbenik rizika za kolonizaciju traheje. Kolonizacija traheje je otkrivena kod bolesnika s traheotomijom, a bila je uzrokovana gram-negativnim patogenima. Kolonizacija ždrijela bila je povezana s kolonizacijom traheje, jer je većina bolesnika imala kolonizaciju ždrijela prije kolonizacije traheje. Kombinacija čimbenika rizika (APACHE II $>18$, dob $>65$ godina, mehanička ventilacija i sedacija) uzrokovala je veću učestalost BSP-a i manju učestalost kolonizacije traheje. BSP je bila češća u bolesnika koji su boravili u JIL-u $>10$ dana i onih s kardiovaskularnim bolestima kao temeljnim poremećajem. Sedacija i prethodna antibiotska terapija bile su u korelaciji s dužim latentnim razdobljem (LAT), dok su veće vrijednosti $\mathrm{pH}$ sadržaja želuca bile povezane s kraćim LAT. Najduži LAT pronađen je u bolesnika koloniziranih bakterijom Acinetobacter spp. Utvrđeno je da su čimbenici rizika koji su ubrzali pojavu BSP-a uzrokovali prethodnu kolonizaciju. Kombinacija čimbenika rizika povećala je vjerojatnost kolonizacije traheje i BSP-a te skratila LAT između kolonizacije traheje i BSP-a.

Ključne riječi: Želudac, ulkus; Bakterije - rast i razvoj; Bolnički stečena upala pluća; Jedinice za intenzivnu skrb; Rizični čimbenici; Traheotomija 